\title{
Linkage and mapping analyses of the normal marking gene $+P$ in the silkworm (Bombyx mori) using SSR markers
}

\author{
G.Q. Wei*, L. Yu*, C.L. Liu, B.J. Zhu and H.J. Ding \\ School of Life Science, Anhui Agricultural University, Hefei, \\ Anhui Province, China \\ *These authors contributed equally to this study. \\ Corresponding author: C.L. Liu \\ E-mail: cyschx@163.com
}

Genet. Mol. Res. 12 (3): 2351-2359 (2013)

Received March 30, 2012

Accepted October 13, 2012

Published January 22, 2013

DOI http://dx.doi.org/10.4238/2013.January.22.1

\begin{abstract}
In the silkworm, Bombyx mori, normal markings are mainly controlled by the $+P$ gene, which is located on the second chromosome. Due to a lack of crossing over in females, reciprocal backcrossed $\mathrm{F}_{1}\left(\mathrm{BC}_{1}\right)$ progenies were used for linkage analysis and mapping of the $+P$ gene based on an SSR linkage map using silkworm strains P50 and H9, which are normal marking and sex-limited marking, respectively. The $+P$ gene was found to be linked to 3 SSR markers. Using a reciprocal $\mathrm{BC}_{1} \mathrm{M}$ cross, we constructed a linkage map of 22.5 $\mathrm{cM}$, with $+P$ mapped at $11.3 \mathrm{cM}$ and the nearest SSR marker S0206 at a distance of $3.0 \mathrm{cM}$. Based on a fine genome map of domesticated silkworms, Kaikoblast analysis showed that the physical distance between the nearest markers (containing the $+P$ gene) is $995 \mathrm{~kb}$. Further analysis showed that BGIBMGA009689, BGIBMGA009688, and BGIBMGA009687 are closer to $+P$, and that BGIBMGA009689 is closest to $+P$, with a physical distance of $19.1 \mathrm{~kb}$.
\end{abstract}

Key words: Silkworm; SSR markers; Linkage analysis; Gene location; $+P$ 


\section{INTRODUCTION}

The mulberry silkworm, Bombyx mori, has been domesticated for silk production for an estimated 5000 years (Xiang, 1995). With the development of biotechnology, B. mori has become the model organism for Lepidoptera, the second most numerous order of insects and one of the best genetically characterized insects. Silkworm larvae possess markings with various categories and are easy to identify, and hence, they are considered an extremely useful resource for research in genetics. Silkworm genetic studies treat normal marking as the normal type for larval marking, which is controlled by the $+P$ gene. The $+P$ gene was mapped to position 0.0 in the silkworm classical genetic linkage group 2 .

With the development of molecular biotechnology, the molecular biology research of $B$. mori has also made considerable progress. Some molecular linkage maps in the silkworm have been constructed by using a variety of molecular markers (Yamamoto et al., 2006), including random amplified polymorphic DNA (RAPD) (Yasukochi, 1998; Yasukochi et al., 2006), restriction fragment length polymorphism (Nguu et al., 2005), amplified fragment length polymorphism (AFLP) (Tan, 2001; Mirhoseini et al., 2009), and simple sequence repeats (SSRs) (Miao et al., 2005).

Microsatellites or SSRs are tandemly repeated units of 1 to 6 nucleotides, which are abundant in prokaryotic and eukaryotic genomes (Field and Wills, 1996). They are PCR-based, highly reproducible, inherited in a Mendelian fashion and polymorphic, generally codominant, and abundant in animal and plant genomes. The SSR technique is a convenient and reliable tool to generate highly polymorphic molecular markers, which greatly facilitate building linkage maps (Litt and Luty, 1989; Tautz, 1989; Weber and May, 1989; Bornet and Branchard, 2001; Schlötterer, 2004). In addition, the use of SSR markers universally present in B. mori for map construction, as opposed to RAPD or AFLP, has the advantage of being non-strain-specific and is thus more suitable for positional cloning. An SSR linkage map has been constructed for the silkworm, which covers all its 28 chromosomes (Miao et al., 2005). By using SSR marking, Li et al. (2006) located the densonucleosis non-susceptible gene $n s d-Z$ on chromosome 15 and Zhao et al. (2011) located the no-glue egg gene $(\mathrm{Ng})$ on chromosome 12. In this study, our objectives were to locate the $+P$ gene through screeningrelated SSR markers, and then to construct the genetic map by calculating the physical distance of $+P$ in accordance with the silkworm database.

\section{MATERIAL AND METHODS}

\section{Silkworm strains and genetic crosses}

The P50 strain, whose larvae have normal marking, and the H9 strain, whose larvae have sex-limited marking, were obtained from the Silkworm Genetics and Breeding Laboratory, School of Life Sciences, Anhui Agricultural University. A single-pair cross between a female (H9) and male (P50) produced the $\mathrm{F}_{1}$ offspring. Owing to the lack of crossing over in females, reciprocal backcrossed $\mathrm{F}_{1}\left(\mathrm{BC}_{1}\right)$ progeny were used for linkage analysis and mapping of the $+P$ gene. For linkage analysis, $\mathrm{BC}_{1}$ progeny from the cross $(\mathrm{H} 9 \times \mathrm{P} 50)+\mathrm{xH} 9{ }^{\lambda}$, together with a second backcross, $\mathrm{BC}_{1}$ progeny from $\mathrm{H} 9 \stackrel{+}{\mathrm{x}}(\mathrm{H} 9 \mathrm{xP} 50) \hat{\partial}$, were used for recombination mapping.

\section{DNA extraction}

DNA samples were extracted from the single pupae of parents and the individuals 
of the backcross population by the standard phenol-chloroform procedure as described by Sambrook et al. (1989). The fat body of pupae was ground with a mechanical homogenizer in a microcentrifuge tube and suspended in DNA extraction buffer $(10 \mathrm{mM}$ Tris- $\mathrm{HCl}, \mathrm{pH} 8.0$; $0.1 \mathrm{mM}$ EDTA, $\mathrm{pH} 8.0 ; 0.5 \% \mathrm{SDS}$ ), which contained $100 \mu \mathrm{g} / \mathrm{mL}$ proteinase $\mathrm{K}$. After digestion with proteinase $\mathrm{K}$ at $56^{\circ} \mathrm{C}$ for 3 to $5 \mathrm{~h}$, phenol-chloroform extraction was carried out, and the DNA was recovered by isopropanol precipitation. The purified DNA was dissolved in TE buffer, $\mathrm{pH}$ 8.0. The DNA concentration was measured by spectrophotometry, and the samples were diluted to a concentration of $10 \mathrm{ng} / \mu \mathrm{L}$ for use in the PCR analysis.

\section{PCR and SSR marker screening}

Standard PCRs $(25 \mu \mathrm{L})$ for SSR locus amplification contained $2.5 \mu \mathrm{L} 10 \mathrm{X}$ buffer $\left(\mathrm{Mg}^{2+}\right), 0.5 \mu \mathrm{L} 10 \mathrm{mM}$ dNTPs, $0.3 \mu \mathrm{L} 5 \mathrm{U} / \mu \mathrm{L}$ Taq polymerase, $1 \mu \mathrm{L} 10 \mu \mathrm{M}$ of each primer, and $10 \mathrm{ng}$ template DNA. The reactions were as follows: initial incubation at $95^{\circ} \mathrm{C}$ for $3 \mathrm{~min}$, $63^{\circ} \mathrm{C}$ for $40 \mathrm{~s}$, and $72^{\circ} \mathrm{C}$ for $1 \mathrm{~min} ; 14$ cycles of $94^{\circ} \mathrm{C}$ for $40 \mathrm{~s}$ [14-step touchdown decreasing the temperature by $0.5^{\circ} \mathrm{C}$ at each step to $56^{\circ} \mathrm{C}(40 \mathrm{~s})$ ] and $72^{\circ} \mathrm{C}$ for $1 \mathrm{~min} ; 24$ cycles of $94^{\circ} \mathrm{C}$ for $40 \mathrm{~s}, 56^{\circ} \mathrm{C}$ for $40 \mathrm{~s}$, and $72^{\circ} \mathrm{C}$ for $1 \mathrm{~min}$; and a final elongation step with extension at $72^{\circ} \mathrm{C}$ for $10 \mathrm{~min}$. The amplified products $(6 \mu \mathrm{L})$ from individual PCRs were resolved by polyacryalmide gel electrophoresis (PAGE) ( $8 \%$ acrylamide gels in $1 \mathrm{X}$ TBE buffer at $90 \mathrm{~V}$ for $6 \mathrm{~h}$ ) followed by silver staining. We carried out polymorphism analysis of the parental using 15 SSR primers based on the SSR molecular linkage map (Miao et al., 2005) by PCR.

\section{Linkage and recombination analysis}

The primer pairs of SSR markers that showed polymorphism between H9 and P50 from 15 SSR markers were used for linkage analysis. We performed PCR amplification of genomic DNA from 22 offspring of the $\mathrm{BC}_{1} \mathrm{~F}$ progeny (11 individuals of normal marking and 11 individuals of sex-limited marking) and detected the primers that linked to the $+P$ gene. To obtain a recombination rate, PCR amplification of genomic DNA of 158 offspring of $\mathrm{BC}_{1} \mathrm{M}$ was performed. These products were detected for analyzing genotypes by PAGE.

\section{Data analysis}

The genetic relationship between markers was determined by maximum likelihood analysis, and the segregation pattern of marker data was analyzed using MAPMAKER version 3.0 (Lander et al., 1987) with the backcross data as an input file. The Kosambi mapping function was used to calculate the distances between marker loci in $\mathrm{cM}$. The genome sequences of markers from the result of data analysis were blasted to analyze the physical distance between $+P$ and SSR markers in the silkworm database (http://silkworm.Genomics.Org.cn).

\section{RESULTS}

\section{Phenotype and genotype of the backcrosses}

All $\mathrm{F}_{1}$ progeny from a cross between an $\mathrm{H} 9$ female and a P50 male showed normal 
marking. Two hundred and seventy-eight $\mathrm{BC}_{1} \mathrm{~F}$ offspring obtained from (H9xP50) $\odot$ xH9 $\curvearrowright$ had a different shade of marking. According to the differences, we separated the progeny into 4 types, where 79 larvae were with plain marking $(Z Z P / P), 67$ with light marking $(Z Z+P / P)$, 72 with normal marking $\left(\mathrm{ZW} \cdot{ }^{-}+P P / P\right)$, and 60 with dark marking $\left(Z W^{-}+P+P / P\right)$. As the difference in marking was not obvious in some individuals, the plain and light marking progeny, which can be clearly distinguished through their marking and sex, were used for analysis, yielding a 1:1 ratio $\left(\chi^{2}\right.$ test, $\left.\mathrm{P}>0.05\right)$ (Table 1$)$ as expected for $Z Z P / P$ versus $Z Z+P / P$ progeny. Similar results were obtained for $158 \mathrm{BC}_{1} \mathrm{M}$ offspring from $\mathrm{H} 9+\mathrm{x}(\mathrm{H} 9 \mathrm{xP} 50){ }^{\top} ; 71$ individuals were with plain marking $(Z Z P / P)$ and 87 larvae with light marking $(Z Z+P / P)(\mathrm{P}$ $>0.05$, ratio $1: 1)$ (Table 1$)$.

\begin{tabular}{|c|c|c|c|c|}
\hline \multirow[t]{2}{*}{ Cross } & \multicolumn{2}{|c|}{ Individual } & \multirow[t]{2}{*}{ Ratio } & \multirow[t]{2}{*}{$\chi^{2}$} \\
\hline & Plain marking & Light marking & & \\
\hline (H9xP50)+xH9 & 79 & 67 & $1.18: 1$ & 0.99 \\
\hline $\mathrm{H} 9+\mathrm{x}(\mathrm{H} 9 \mathrm{xP} 50) \hat{\partial}$ & 71 & 87 & $0.82: 1$ & 1.62 \\
\hline
\end{tabular}

\section{Screening for polymorphism of SSR markers}

Figure 1 shows the result of some electrophoretograms of polymorphism screening between $\mathrm{H} 9$ and P50. To find polymorphic primers, the products from individual PCRs using the same primer pair in different DNA templates (H9 and P50) were resolved by PAGE, and the samples were placed in adjacent wells. The result of some primer pairs through PCR amplification was unsatisfactory, where polymorphism between H9 and P50 could not be determined by repeating several times, so we abandoned these primers to avoid influencing subsequent experiments. Finally, we obtained 10 polymorphic markers from 15 SSR markers, including S0202, S0204, S0205, S0206, S0208, S0209, S0210, S0211, S0213, and S0214.

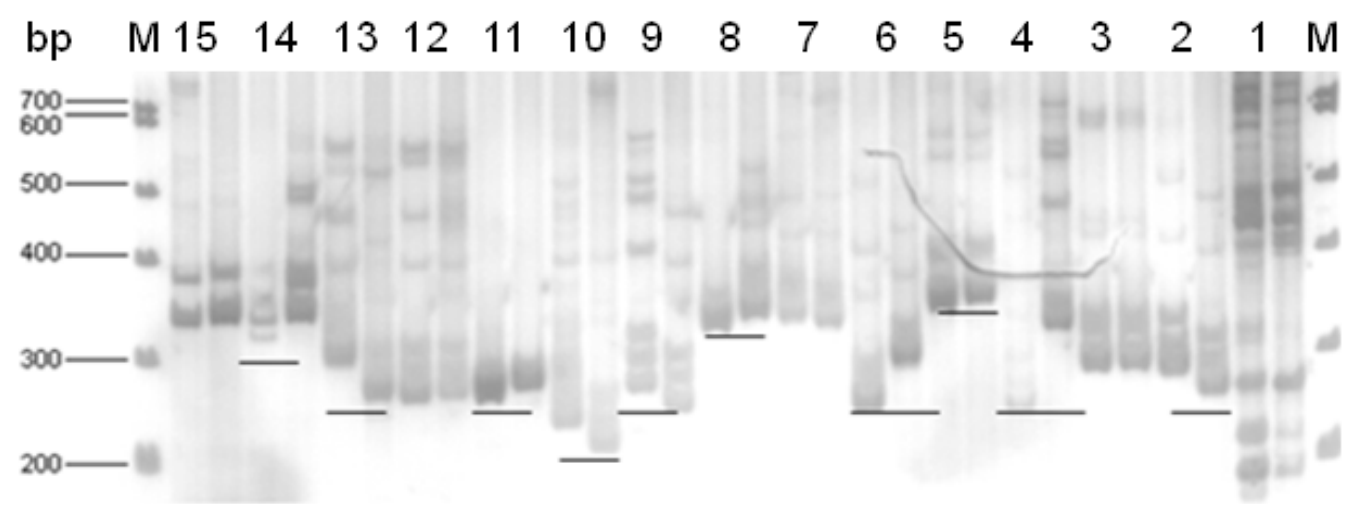

Figure 1. Electrophoretogram of polymorphism screening between H9 and P50. Lane $M=$ DNA marker; lanes 1 to $15=15$ SSR primer pairs. 


\section{Linkage analysis of SSR markers with the $+P$ gene}

In B. mori, linkage analysis can be carried out efficiently because no crossing over occurs in females. The polymorphic markers, which were found from H9 and P50 by polymorphism screening, were used to analyze the genetic inheritance pattern in 22 offspring from $\mathrm{BC}_{1} \mathrm{~F}$ progeny. Because SSRs are inherited in a Mendelian fashion and exhibit codominant alleles, we screened SSR markers for linkage to $+P$ by comparing the pattern shown by groups of 22 individuals in $\mathrm{BC}_{1} \mathrm{~F}$ progeny with the $\mathrm{F}_{1}$ and parent $\mathrm{P} 50$ pattern. If the individuals with light marking were all of the same $\mathrm{F}_{1}$ pattern (heterozygous, $+P / P$ ), the SSR marker was confirmed to be linked to the $+P$ gene; otherwise, the SSR marker was discarded (Figure 2). We continued with this type of analysis until we had analyzed all the polymorphic markers. Thus, a total of 3 SSR markers (S0202, S0206, and S0211) were identified to be linked to $+P$ (Table 2, Figure 2).

\section{$122 \quad 3 \quad M \quad 4 \quad 5 \quad 6 \quad 7 \quad 8 \quad 910111213141516171819202122232425$}

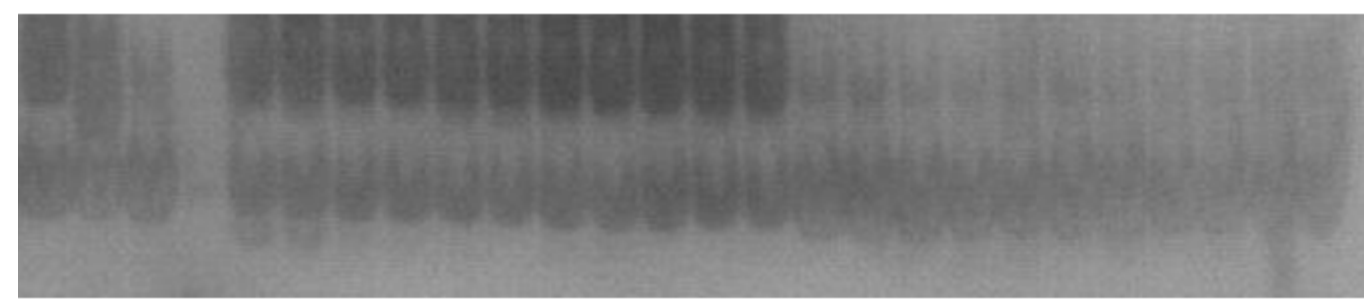

Figure 2. Amplification of individuals in $\mathrm{BC}_{1} \mathrm{~F}$ by S0202. Lane $1=(\mathrm{H} 9 \mathrm{xP} 50) \mathrm{F} 1$, female of the $\mathrm{BC}_{1} \mathrm{~F}$ population; lane 2 $=$ parent $\mathrm{P} 50$; lane $3=$ parent $\mathrm{H} 9$, male of the $\mathrm{BC}_{1} \mathrm{~F}$ population; lane $M=\mathrm{DNA}$ marker; lanes 4 to $14=$ individuals with light marking type in $\mathrm{BC}_{1} \mathrm{~F}$ cross; lanes 15 to 25 = individuals with plain marking type in $\mathrm{BC}_{1} \mathrm{~F}$ cross.

\begin{tabular}{llc}
\multicolumn{2}{c}{ Table 2. SSR loci linked to $+P$. } & \\
\hline Locus symbol & Primer sequence (5'-3') & Allele size (bp) \\
\hline S0202 & TTATTGACCTCCCACATCCCC & 228 \\
S0206 & GGTGCATTTTGGGAAGATAGTGTA & 243 \\
S0211 & TTACTGGGTCGGAAGGATGGA & 271 \\
& AAGGTAGAAGGGGAAGAGGTCG & \\
\hline
\end{tabular}

\section{Linkage map construction of the $+P$ gene with SSR markers}

Since there is no crossing over in females, the initial analysis was only done in the SSR markers that were linked to normal marking. To determine the marker order and relative distance with respect to $+P$, we carried out genotyping of the 3 SSR markers that were linked to $+P$ using 158 surviving $\mathrm{BC}_{1} \mathrm{M}$ progeny. As shown in Figures 3 and 4 , we scored individual offspring in which the inheritance pattern showed either the same H9 pattern (homozygous, designated 1) or the same $F_{1}$ pattern (heterozygous, designated 2) for each SSR marker. The location of each marker was initially established through a 3-point comparative analysis of the number of recombinants in the sorted data, and the recombination fractions were then calculated from the whole data set using MAPMAKER 3.0. 


\section{$1 \quad 2 \quad 3 \quad 4 \quad 5 \quad 6 \quad 7 \quad 8 \quad 910111213141516171819$ M 20}

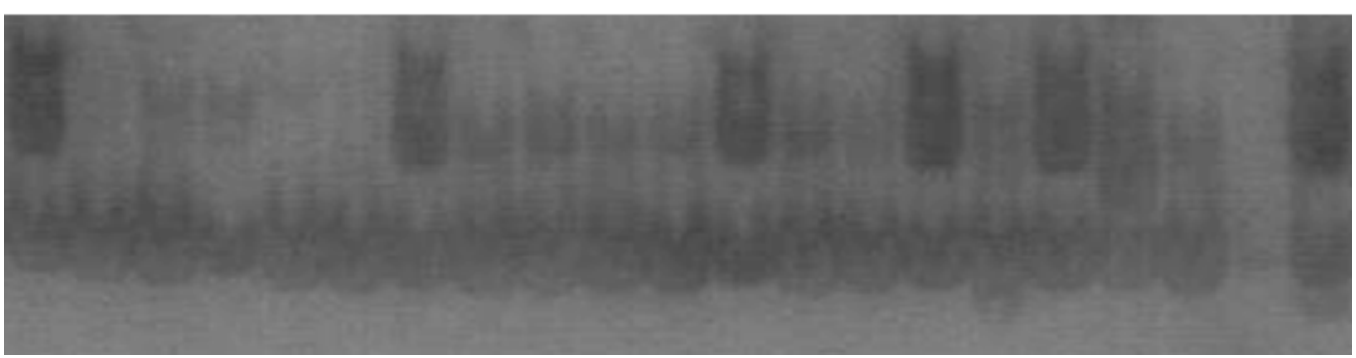

Figure 3. Amplification of individuals in $\mathrm{BC}_{1} \mathrm{M}$ by S0206. Lanes 1 to $18=$ plain marking individuals with $\mathrm{BC}_{1} \mathrm{M}$ cross. Lane $19=$ parent $\mathrm{H} 9$, female of the $\mathrm{BC}_{1} \mathrm{M}$ populations; lane $M=$ DNA marker; lane $20=(\mathrm{H} 9 \times \mathrm{P} 50) \mathrm{F}_{1}$, male of the $\mathrm{BC}_{1} \mathrm{M}$ populations.

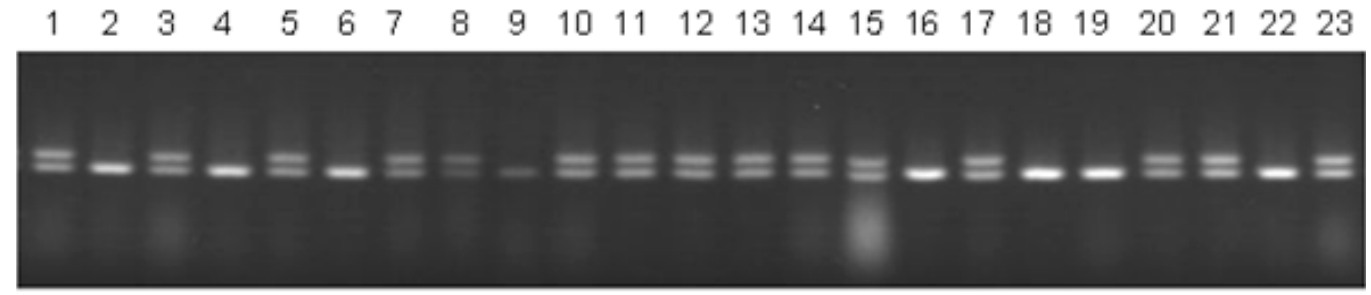

Figure 4. Amplification of individuals in $\mathrm{BC}_{1} \mathrm{M}$ by S0211. Lane $1=(\mathrm{H} 9 \times \mathrm{P} 50) \mathrm{F}_{1}$, male of the $\mathrm{BC}_{1} \mathrm{M}$ populations; lane $2=$ parent $\mathrm{H} 9$, female of the $\mathrm{BC}_{1} \mathrm{M}$ populations; lanes 3 to $23=$ light marking individuals with $\mathrm{BC}_{1} \mathrm{M}$ cross.

The $\mathrm{BC}_{1} \mathrm{M}$ progeny generated the recombination map shown in Figure 5. The order of the SSR markers in the linkage group was established as follows: S0202, S0206, $+P$, and S0211. The linkage map was $22.5 \mathrm{cM}$ in length, and $+P$ was mapped at $11.3 \mathrm{cM}$. S0206, which is the SSR marker identified as being most closely linked to $+P$, was mapped at a distance of $3.0 \mathrm{cM}$ from $+P$.

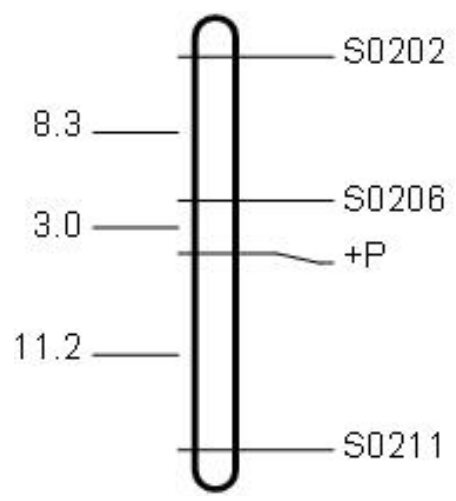

Figure 5. Mapping of the $+P$ gene with SSR markers determined by analysis of the $\mathrm{BC}_{1} \mathrm{M}$ progeny of the cross $\mathrm{H} 9 \bigcirc \mathrm{x}(\mathrm{H} 9 \mathrm{xP} 50){ }^{\lambda}$. 


\section{Analysis of physical distance between $+P$ and SSR markers}

According to the results of the genetic map, we blasted the genome sequences that were closest to $+P$. The Kaikoblast results showed that the physical distance between S0206 and S0211 is $995 \mathrm{~kb}$ (Table 3). The S0206 and S0211 were located in the nscaf27 in the fine genome map of the domesticated silkworm. Through further analysis of the up- and downstream sequences of S0206 and S0211 in the silkworm database, we found that 3 genes (BGIBMGA009690, BGIBMGA009689, and BGIBMGA009688) are closer to $+P$, and the physical distance of BGIBMGA005835, $44 \mathrm{~kb}$, is closest to $+P$ (Figure 6).

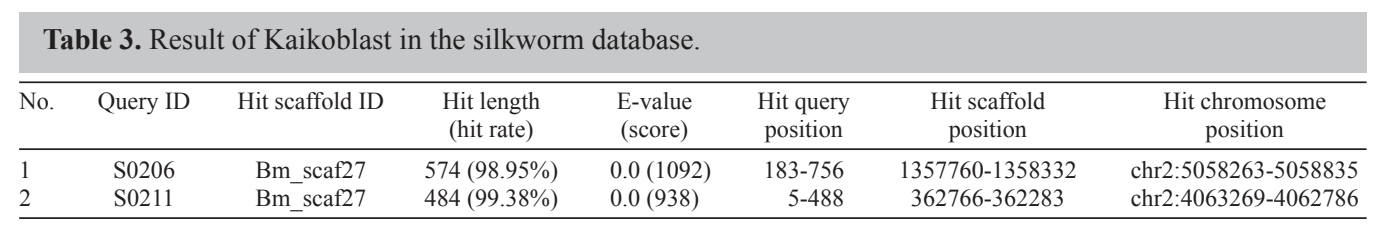

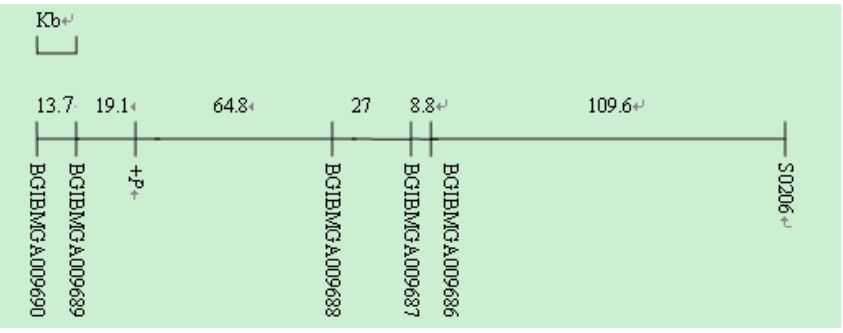

Figure 6. Physical distance between $+P$ and molecular markers.

\section{DISCUSSION}

In this study, the $+P$ gene was found to be linked to 3 SSRs. This was evident from the profile of the $3 \mathrm{SSRs}$ in $22 \mathrm{BC}_{1} \mathrm{~F}$ individuals. A linkage map of $22.5 \mathrm{cM}$ for the linkage group was constructed, with $+P$ mapped at $11.3 \mathrm{cM}$ and with the closest marker being S0206. The order of the SSR markers and the $+P$ gene was as follows: S0202, S0206, $+P$, and S0211. S0206 was most closely linked to $+P$ with a distance of $3.0 \mathrm{cM}$ from $+P$ (Figure 5 ). The Kaikoblast results in the fine genome map of the domesticated silkworm (B. mori) showed that the physical distance between S0206 and S0211 is $995 \mathrm{~kb}$ (Table 3). The S0206 and S0211 were located in the nscaf 27 in fine genome map of the domesticated silkworm. We also found that 3 genes (BGIBMGA009690, BGIBMGA009689, and BGIBMGA009688) are closer to $+P$, and that the physical distance of BGIBMGA005835, $44 \mathrm{~kb}$, is closest to $+P$ (Figure 6).

In screening SSR markers, some showed no polymorphism or could not be assessed for polymorphism because the genetic relationship was too close between parents and the differences could not be visualized by PAGE. The marker density of this molecular genetic map is relatively low and the backcross population is small. Due to the limited number of mapped SSR and related molecular markers, it is probably premature to establish a quantitative relationship between the physical and genetic maps; this conclusion is reinforced by the fact that only single matches were identified between SSR markers and sequenced contigs. With the 
gradual increase in molecular markers on the genetic map, these genetic linkage groups will facilitate the estimation of marker density needed for map-based cloning, the ordering of genomic contigs, and the establishment of a complete physical map.

The identification of these markers represents an important step towards positional cloning of the gene with these markers as tags. It will be useful in the fine mapping and cloning of the $+P$ gene based on the SSR linkage map. In the domesticated silkworm, sex-limited marking, which is widely used for male silkworm selection in silkworm breeding in China, is very important not only in evolution but also in the industry. Future research will focus on finding more closely linked molecular markers to facilitate marker-assisted selection with the long-term goal of fine mapping and cloning of the $+P$ gene. It is useful for research on the regulatory mechanism of sex-limited marking silkworm and the breeding of sex-limited silkworm strains.

\section{ACKNOWLEDGMENTS}

Research supported by the China Agriculture Research System (\#CARS-22-SYZ10), the Anhui Agriculture Research System (\#ahnycytx-16), and the Anhui Provincial Natural Science Foundation (\#11040606M98).

\section{REFERENCES}

Bornet B and Branchard M (2001). Nonanchored inter simple sequence repeat (ISSR) markers: reproducible and specific tools for genome fingerprinting. Plant Mol. Biol. Rep. 19: 209-215.

Field D and Wills C (1996). Long, polymorphic microsatellites in simple organisms. Proc. Biol. Sci. 263: 209-215.

Lander ES, Green P, Abrahamson J, Barlow A, et al. (1987). MAPMAKER: an interactive computer package for constructing primary genetic linkage maps of experimental and natural populations. Genomics 1: 174-181.

Li M, Guo Q, Hou C, Miao X, et al. (2006). Linkage and mapping analyses of the densonucleosis non-susceptible gene nsd-Z in the silkworm Bombyx mori using SSR markers. Genome 49: 397-402.

Litt M and Luty JA (1989). A hypervariable microsatellite revealed by in vitro amplification of a dinucleotide repeat within the cardiac muscle actin gene. Am. J. Hum. Genet. 44: 397-401.

Miao XX, Xub SJ, Li MH, Li MW, et al. (2005). Simple sequence repeat-based consensus linkage map of Bombyx mori. Proc. Natl. Acad. Sci. U. S. A. 102: 16303-16308.

Mirhoseini SZ, Rabiei B, Potki P and Dalirsefat SB (2009). Linkage map construction for silkworm (Bombyx mori L.) based on amplified fragment length polymorphism markers. Iran. J. Biotechnol. 7: 28-36.

Nguu EK, Kadono-Okuda K, Mase K, Kosegawa E, et al. (2005). Molecular linkage map for the silkworm, Bombyx mori, based on restriction fragment length polymorphism of cDNA clones. J. Insect Biotechnol. Sericol. 74: 5-13.

Sambrook J, Fritsch EF and Maniatis T (1989). Molecular Cloning: A Laboratory Manual. Cold Spring Harbor Laboratory Press, Cold Spring Harbor.

Schlötterer C (2004). The evolution of molecular markers - just a matter of fashion? Nat. Rev. Genet. 5: 63-69.

Tan YD, Wan C, Zhu Y, Lu C, et al. (2001). An amplified fragment length polymorphism map of the silkworm. Genetics 157: $1277-1284$.

Tautz D (1989). Hypervariability of simple sequences as a general source for polymorphic DNA markers. Nucleic Acids Res. 17: 6463-6471.

Weber JL and May PE (1989). Abundant class of human DNA polymorphisms which can be typed using the polymerase chain reaction. Am. J. Hum. Genet. 44: 388-396.

Xiang ZH (1995). Genetics and Breeding of the Silkworm. Chinese Agriculture Press, Beijing.

Yamamoto K, Narukawa J, Kadono-Okuda K, Nohata J, et al. (2006). Construction of a single nucleotide polymorphism linkage map for the silkworm, Bombyx mori, based on bacterial artificial chromosome end sequences. Genetics 173: 151-161.

Yasukochi Y (1998). A dense genetic map of the silkworm, Bombyx mori, covering all chromosomes based on 1018 molecular markers. Genetics 150: 1513-1525. 
Yasukochi Y, Ashakumary LA, Baba K, Yoshido A, et al. (2006). A second-generation integrated map of the silkworm reveals synteny and conserved gene order between lepidopteran insects. Genetics 173: 1319-1328.

Zhao XM, Wei GQ, Liu CL, Zou CR, et al. (2011). Linkage and mapping analyses of the no glue egg gene Ng in the silkworm (Bombyx mori L.) using simple sequence repeats (SSR) markers. Afr. J. Biotechnol. 10: 9549-9556. 